\title{
The Situation and Problems of Adult Education in China
}

\author{
on the Perspective of Lifelong Education
}

\author{
Donglin $\mathrm{Yu}$ \\ Culture Transmission Academy, Jiujiang University \\ China, 332005 \\ e-mail: spydz@163.com
}

\begin{abstract}
The adult education is an important part of the lifelong education systems. To develop the adult education is an important principle for China's economic, social and educational development. Currently, the status quo of the adult education is not optimistic, there are educational philosophy, educational orientation bias. Therefore, it should be efforts from the following aspects: On the macro level, strengthen the research of lifelong education, out of ideas misunderstanding; deepen the reform of the education system, the formation of a national committee "lifelong education" unified management of national resources and relationships education; increase efforts to promote lifelong learning and the adult education policy legislation of our country, and improve science policy formulation and decision-making mechanisms. On the micro level, to create "credit bank", to set up "courses supermarket", to create "community learning platform" and so on.
\end{abstract}

Keywords-lifelong education; the adult education; social development

\section{INTRODUCTION}

The adult education is the historical development of human society to a certain stage of the product, is a new form of education under the background of society, politics, and economy. With China's accession to WTO, foreign capital also led the city to permeate education, social education and private schools springing up, new educational philosophy, educational methods and new talent, the quality concept of forming a powerful impact on the adult education. In this situation, how to get out of the concept of the adult education and practical difficulties misunderstanding is an urgent issue.

First, putting forward and practice of the lifelong learning concept.

In the December of 1965, in the third meeting of the Committee of UNESCO International Commission on Education for Adults, the famous French educator Lengrand that "on lifelong education"( in English ) of the motion. The energetic efforts of UNESCO, the European Union and other international organizations and institutions, the concept of lifelong education quickly swept the world, and show as lively practice in Japan, the U.S, Britain and other countries. Japan is one of the world's oldest and most are keen to develop lifelong education. Back in the mid-1960s, the concept of lifelong education became popular in Japan in the early 1970s, Japan began a lifelong education level of the comprehensive reform of the entire education system. The U.S government actively promoted the development of the adult education since World War II. As early as 1966, promulgated the " The adult education" , and in 1968-1984 years has conducted seven changes. 1976, promulgated the "lifelong learning", the scope of the provisions of lifelong learning, proposed the establishment of the education agency, research funding lifelong learning methods. Britain's lifelong education can be traced back in 1812, when the Reverend Charles Thomas port city of Bristol in the UK has opened schools for adults. Good development of the adult education for the British practice of modern concept of lifelong education foundation. The concept of lifelong education which formally began in 1972, "Russell report", the report proposed a "permanent education" argument, and suggested that re-established the British education system. In 1986, the British developed national occupational skills standards, beginning in the establishment of lifelong vocational education system. Lifelong education is not like the UK, Japan and the United States, no specially formulated "The adult education" or "Lifelong Education Act",but the above content into learning and vocational skills training to continue being. In other words, focus on the continuation of the British national educational traditions, emphasizing lifelong education embodied in the concept of the existing legal and policy framework. China from exposure to the concept of lifelong education building institutional mechanisms than in Western countries have recent 20 years. But since the reform and opening up, promote the concept of lifelong education, policy development and system construction has accelerated signs. Whether in 1995 to develop the "People's Republic of China Education Law" was the first National Congress Party, a large seventeenth report, regarded the "perfect modern national education system and lifelong education system" put on the important agenda. Eighteen report made it clear that "improve the lifelong education system, building a learning society".

\section{THE STATUS AND ITS PROBLEMS OF THE ADULT EDUCATION.}

The transition from the concept of lifelong education is still a long way to policies and even the process of localization in China. Construction of China's lifelong 
education system is still in the process of advancing. Currently, as the current situation of China's the adult education an important part of lifelong education is not optimistic; there are still many problems to be solved. Specifically in the following four areas:

A. The educational philosophy and positioning deviation. Growth and overall development of lifelong education is one of the core education as an ongoing process throughout the person's lifetime.

However, from our lifelong education policy involving text content point of view, the lifelong education as the adult education, and vocational skills training and job -oriented training tends to be very obvious. Its basic purpose is to develop national construction trades training or professional and technical personnel. This practical, utilitarian features, apparently with the international community based on education, public welfare and welfare objectives, such as expanded lifelong education is very different. From the point of view of education orientation, the adult education as academic education, especially college -level education. Since college enrollment, this bias educational philosophy and positioning is particularly striking, negative impact is obvious.

\section{B. A sharp reduction in the number of students, poor school conditions.}

Bring to a common higher education enrollment of the adult education enrollment huge impact, a sharp drop in the overall education of students, students are increasingly distributed internal imbalances, popular professional Fortunately, the general professional unsustainable popular professional few. Currently, the adult education mainly depend Top high equipment, teachers and all forces to school, thus leading to poor school conditions, lack of human and financial resources put into it, even the adult education as a means of income generation. The adult education and non-academic education structure is irrational, the proportion of academic education is too high, the intensity of the nonacademic education is not enough, it is not conducive to lifelong learning system.

The course structure aging, uneven quality of teaching curriculum development and practice of the adult education needs significant discord, theoretical knowledge too much, too little practical knowledge of the structure of a single course, knowledge is divided too small, most of the adult education courses in subjects still system construction, curriculum, textbooks were not reflect the characteristics of the adult education. According to the survey: only $2.1 \%$ of the adult students in the school curriculum structure should consider maintaining the status quo, but there are more than $56 \%$ of the students believe that teaching materials should be enhanced advanced and practical.

All in all, our the adult education, the adult education especially worrying status quo, the school principal for the adult education orientation is not accurate enough, its function is also know there is a deviation .

\section{THE MEASURES OF THE CURRENT PROBLEMS OF THE ADULT} EDUCATION.

Needless to say, the current Chinese the adult education do exist many problems. For these problems, we should be based on reality, learn from advanced international experience, to grasp and solve the macro and micro levels. From a macro perspective, the main idea is to do a good job and value guide, which need to strengthen theoretical study of lifelong education; to do policy and legal safeguards, which need to strengthen policies and laws of the intensity of lifelong education and the adult education; to make organizational security, which requires the State Board of Education to build lifelong manages all educational resources and educational relations, the establishment of regional chapters around the local conditions. From the micro level, mainly set up a "credit bank", set up "courses supermarket", build "community learning platform", and so on.

\section{A. strengthen theoretical study of lifelong education.}

Lagging behind theoretical study of lifelong education, leading to the practice of understanding of the relevant policy-oriented bias even vague, difficult -depth legislative dilemma has become increasingly evident. Such as Shanghai in 2011 to develop the "Regulations of Shanghai to promote lifelong education", because the lag, poor implementation of the policy of theoretical studies, caused a legislative evolution of vocational training and education of the elderly has become a place of lifelong education regulations. The adult education should be people-oriented to the needs of adults as a foothold to improve the quality of adult individuals as the core, building management system and curriculum system of the adult education. Therefore, we should strengthen theoretical study of lifelong education, good ideas and values guide.

\section{$B$. increase the intensity of the adult education and lifelong education policy of the legislation.}

Japan, the U.S, Britain and other countries lifelong education and the adult education was a huge success, one of the key (and they have in common) is that through the development of relevant policies and laws, and continue to improve in practice, thus effectively protect lifelong education and the adult education -related work to proceed smoothly and fruitful. So this is the final implementation of a well-established idea of lifelong education and indispensable path. In addition, we have actively participated in the establishment of the public, academics suggestions and co-ordination of government policy formulation and decision-making mechanisms to ensure that our policy of the adult education, scientific decision-making .

\section{C. deepen education reform, the formation of the national administrative body ruled over the resources and relationships education.}

At present, China's education system fragmentation phenomenon exists, so a lot of idle resources in some schools can not play its due role and other issues. Founder of the adult education in our various colleges and universities, for example, have a Department of Education in charge of the Ministry of Education in charge of the State Ethnic Affairs Commission in charge and so on. Universities are not the 
same level, there is the vice ministerial level, there are departmental level, there is a deputy department. This traditional educational system built on "with the right segmentation concept". With the right split "is a form of the same kind of power between different agencies or on the lower level segmentation, the scope of the powers of the fuzzy boundaries of space overlapping powers to "fruit tree or tree structure" is the basic characteristic morphology. The "exclusive rights division" is the same kind of power to try to form a relatively complete assigned to the appropriate members of the organization, powers relatively clear boundaries clear, with "fruit or fruit structure structures" is the basic characteristic morphology . Reform of the education system , first go to the administration of the education system , to the current based on the "same right split" design concept "fruit tree or tree structure" morphology updated based on the "exclusive right to split" concept "fruit or fruit structure structures" educational administration system. Therefore, it should be said that the formation of unified management of the National Committee of "lifelong learning" national educational resources and relationships at all levels of the local branch of the establishment of regional local conditions, after an important way to break the current educational resource fragmentation and conflict of interest issues.

\section{D. set up "credit bank".}

For the adult education student cultural foundation is weak, lack of motivation, level uneven features available on the reform of personnel training and assessment methods, the implementation of vocational education and general education exchange, after pre-vocational education and vocational education convergence, and non- academic education combining academic education, the establishment of an open and flexible, wide choice, and learn something to teach education "overpass" building "credit Bank", the implementation of the credit system. To by non-academic, non-formal learning outcomes, access to informal education given attention, be identified credits, lowering the threshold established in the relevant system of certification of learning outcomes, conversion, etc., from students to reality, close to "education for cultured human nature " to meet the needs of the adult education students personality development.

\section{E. the creation of "curriculum supermarkets".}

The adult education colleges under the concept of lifelong education should be based on the nature of human needs, courses from the "moral, intellectual, physical, aesthetic , labor, arts", such as multiple angles, not just based on professional knowledge, but also focus on practical ability and professional skills, establish professional ethics, the adult education campus culture shaping needs of life, respecting the needs of the people themselves, improve training quality, focusing on "learning", the adult education classroom fight the fine type, diverse "curriculum supermarket" and based on the students' practical difficulties, the implementation of flexible educational system, to solve engineering contradictions, individualized instruction.

\section{F. build "community learning platform".}

The concept of lifelong education goals and consistent community education, they have emphasized the inclusion of education in the social system, becoming the duties, powers and obligations of the total members of society, creating human beings to learn, always able to learn, to learn social atmosphere everywhere, and ultimately to improve the living situation, improve the quality of life and enhance the overall quality of the community, to achieve the purpose of human happiness needs. The adult education should be into the community, close to the community, to achieve effective integration of university resources with community needs, so that community members in the area of the adult education in colleges and universities can always "feel to learn", "learning experience", "experiential learning" and "lifelong learning".

\section{CONCLUSION}

In short, the above efforts, from the macro level, strengthening the concept and value guidance, strengthening policy and legal protection, strengthening organizational security; from the micro level, through the establishment of "Credit Bank", the creation of "curriculum supermarket", build "community learning platform", design "to teach Tips" and other initiatives, the expansion of education and educational space objects autonomy; further improve the adult education institutional mechanisms to promote education at all levels vertical convergence, horizontal communication, and ultimately build up a flexible and open system of lifelong education.

\section{REFERENCES}

[1] Lu Wei gang. Lifelong Education College The adult education Development Dilemma and Countermeasures[J]. Chinese adult education. 2005(10)

[2] Yu Xiao bo. Development course and Thinking of Adult Higher Education[J]. Changsha University of Electric Power. 2001 (01)

[3] Wang $\mathrm{Zi}$ lin. new situation of the adult education development[J]. Chinese adult education 2007 (20)

[4] Luo Ming ya. Status of the adult education, problems and countermeasures \{D]. Yunnan Normal University Thesis .2006 (01)

[5] Wen Jin. Situation Analysis of The adult education and Countermeasures[J]. Yunmeng Science 2002 (01)

[6] Wang Cheng li. Adult Teaching Exploration [J]. Chinese The adult education.2004 (10)

[7] Tang Ji yun. Characteristics and Teaching Principles of The adult education[J]. Chinese The adult education .2004 (12)

[8] Ao $\mathrm{Yu}$ wen. Thinking features and management reform of the adult education the adult education [J]. Education and Vocational.2008 (03)

[9] Liu Yan jiang. Prince original status and development ideas .21 Century The adult education [J]. Education Forum.2006(03)

[10] Li Cui hua. Grasp the characteristics of the adult education, improve teaching quality [J]. Liaoning College of Education .1998 (05)

[11] $\mathrm{Xu}$ Yan. The adult education Development Strategy of Lifelong Education explore[J]. Hubei Radio and Television University.2013 (08)

[12] Tan Chuan sheng. Lifelong Education Development Research under the transformation $[\mathrm{J}]$. Changsha University of Technology (Social Science Edition) 2013 (01)

[13] [13].Guo Hui nan. Contemporary International lifelong education policy $[\mathrm{J}]$. Foreign primary and secondary education $.2013(01)$ 